\section{THE MODE OF IMMUNOPOTENTIATING ACTION OF BESTATIN: ENHANCED RESISTANCE TO LISTERIA MONOCYTOGENES INFECTION}

\author{
Yasuko Harada, * Akira Kajiki, ** \\ KaZUyuki Higuchi, Tsuneo Ishibashi* \\ and Masahiro TAKamoto* \\ Research Institute for Diseases of the Chest, \\ Faculty of Medicine, Kyushu University, \\ Maidashi, Higashiku, Fukuoka, Japan \\ (Received for publication April 30, 1983)
}

UMEZAWA et al. have found that bestatin, isolated from culture filtrate of Streptomyces olivoreticuli, is a specific inhibitor of aminopeptidase B and leucine aminopeptidase which are located on the surface membrane in various mammalian cells including lymphocytes and macrophages ${ }^{1,2)}$. This chemically defined immunopotentiator was shown to enhance delayed type hypersensitivity (DTH) response and antibody production and to exert an antitumor action ${ }^{3 \sim 5)}$. The present studies were undertaken to study its effect on the resistance to Listeria monocytogenes (LM) infection.

Female, specific pathogen free, inbred DDD mice were obtained from the animal supply center in Kyushu University. Eight- to ten-week old mice were used in the experiments.

Bestatin was kindly provided by Prof. S. OKA and Prof. H. Umezawa, Institute of Microbial Chemistry, Tokyo, Japan. It was prepared by Nippon Kayaku Co., Ltd. It was dissolved in sterile saline and was administered intravenously, intraperitoneally or orally in a volume of $0.1 \mathrm{ml}$.

The soluble antigen of LM was prepared from culture filtrates of $\mathrm{LM}^{6,7)}$. Briefly, protein free medium was prepared by dialysis of 10 -fold concentrated solution of Trypticase soy broth against 10 volume of distilled water for 24 hours at $4^{\circ} \mathrm{C}$. The dialysate was autoclaved, inoculated with LM and incubated for 18 hours at $37^{\circ} \mathrm{C}$ with continuous shaking $(150 \mathrm{rpm})$. Bacteria were removed

Present address: *National Hospital Ohmuta, Tachibana 1044-1, Ohmuta, 837 Japan.

** IInd Department of Internal Medicine, University of Occupational and Environmental Health, Iseigaoka, Yahata-Nishiku, Kitakyushu, 807 Japan. by centrifugation $(3,300 \times g)$ and Millipore filter (GS $0.22 \mu \mathrm{m}$ ). The supernatant was concentrated by Diaflo Ultra filtration membrane (PM 30, Amicon) and lyophilized. This powder was used as an antigen for foot pad test (FPT).

Listeria monocytogenes (strain EGD) was provided originally from Dr. G. B. MACKANESS (Trudeau Institute, Saranac Lake, N.Y., USA). Bacterial suspensions were made as described previously ${ }^{7}$. The mean lethal dose $\left(\mathrm{LD}_{50}\right)$ in DDD mice was routinely less than $2 \times 10^{3}$ bacteria. Mice were infected iv with the dose near the $\mathrm{LD}_{50}$ in a volume of $0.1 \mathrm{ml}$. The course of infection was followed quantitatively by bacteria counts in the liver and spleen as described previously? ${ }^{7}$. The DTH to LM was measured by FPT using an eliciting dose of $20 \mu \mathrm{g}$ listerial antigen. The spreading of peritoneal macrophages was measured as described previously.?)

Test for significance was performed using the Student's t-test. The survival rate between experimental groups was analyzed according to the generalized Wilcoxon test. A $P$-value of less than 0.05 was considered statistically significant.

Firstly, mortality studies were performed in bestatin-treated mice. Mice were divided into two groups. One group of mice was administered orally with $100 \mu \mathrm{g}$ of bestatin daily for 5 days. The other group served as normal control. Each group consisted of 15 mice. All mice were concurrently infected iv with $1.1 \times 10^{3} \mathrm{LM}$ an hour after the last administration of bestatin. The results are presented in Fig. 1. The death of mice

Fig. 1. Per cent survival of bestatin-treated mice infected with LM.

Control and bestatin-treated mice were infected iv with $1.1 \times 10^{3} \mathrm{LM}$ an hour after the last administration of bestatin.

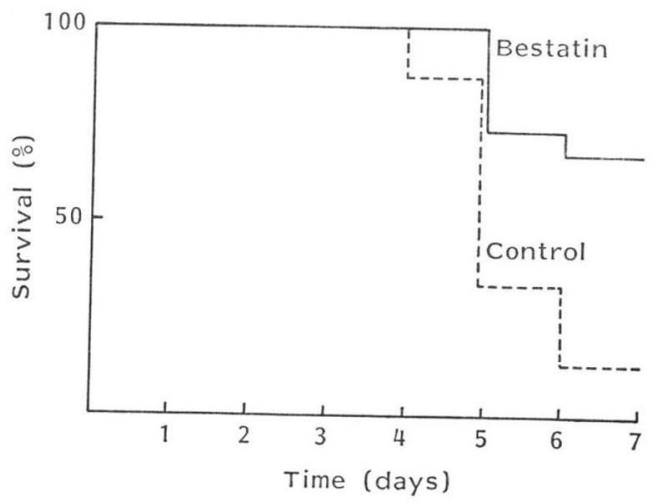


Fig. 2. Growth of LM in the liver and spleen in bestatin-treated mice.

Control (O) and bestatin-treated ( ) mice were infected iv with $1.7 \times 10^{3} \mathrm{LM}$ an hour after the last administration of bestatin.

Each point represents the mean of five.

* $P<0.05$, ** $P<0.001$ in comparison with control.

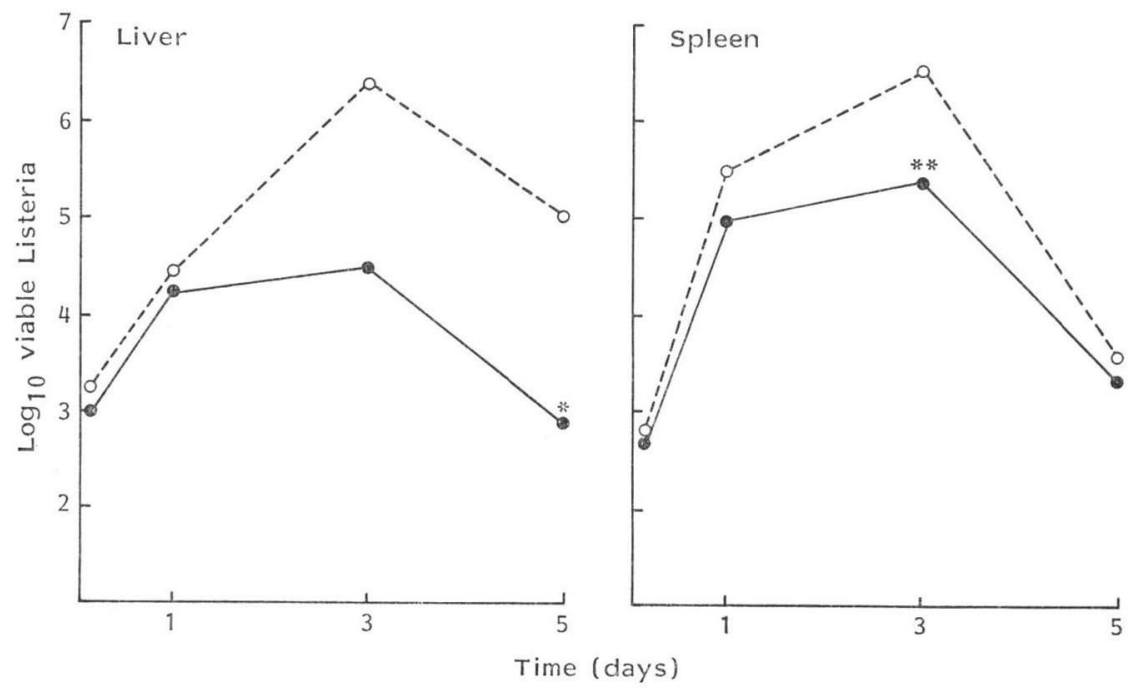

Table 1. Macrophage spreading after LM infection.

\begin{tabular}{cccccc}
\hline & \multicolumn{2}{c}{ Day 1} & & \multicolumn{2}{c}{ Day 3} \\
\cline { 2 - 3 } \cline { 5 - 6 } Group & $\begin{array}{c}\text { No. of } \\
\text { peritoneal cells } \\
\left(\times 10^{5}\right)\end{array}$ & $\%$ spreading & & $\begin{array}{c}\text { No. of } \\
\text { peritoneal cells } \\
\left(\times 10^{5}\right)\end{array}$ & $\%$ spreading \\
\hline Control & $72 \pm 17$ & $6.1 \pm 3.3$ & & $27 \pm 4$ & $8.6 \pm 3.6$ \\
Bestatin & $141 \pm 50^{*}$ & $12.4 \pm 4.2^{* *}$ & & $37 \pm 14$ & $12.2 \pm 3.8$ \\
\hline
\end{tabular}

All values are expressed as the mean of five \pm S.D.

* $P<0.01$ in comparison with control.

** $\quad P<0.05$ in comparison with control.

was not observed after the 7th day of infection. The survival rates were $67.0 \%$ in bestatin-treated mice, $13.7 \%$ in normal controls respectively. The difference between both groups was significant to $P<0.01$.

In the next experiment, the course of infection was followed by quantitative enumeration of bacteria in the liver and spleen. Mice were divided into two groups. Hundred $\mu \mathrm{g}$ of bestatin was given iv daily for 5 days. Mice were concurrently infected iv with $1.7 \times 10^{3} \mathrm{LM}$ an hour after the last injection of bestatin. The results are presented in Fig. 2. The growth of LM in the liver and spleen was clearly inhibited in bestatin-treated mice.

Macrophage spreading in bestatin-treated mice
Table 2. DTH response to LM antigen.

\begin{tabular}{lccc}
\hline \multirow{2}{*}{ Group } & \multicolumn{3}{c}{ Foot pad test } \\
\cline { 2 - 4 } & Day 5 & Day 7 & Day 9 \\
\hline Control & $3.6 \pm 1.8$ & $3.5 \pm 1.4$ & $5.6 \pm 0.9$ \\
Bestatin & $7.2 \pm 3.6$ & $7.5 \pm 2.3^{*}$ & $7.0 \pm 2.9$ \\
\hline
\end{tabular}

The FPT value represents the mean of five \pm S.D. (0.1 mm).

* $P<0.05$ in comparison with control.

during LM infection was examined. Mice were divided into two groups. One group of mice served as controls. The other group of mice was injected ip with $100 \mu \mathrm{g}$ of bestatin daily for 5 days. All mice were concurrently infected iv 
with $1.6 \times 10^{3} \mathrm{LM}$ an hour after the last injection of bestatin. Spreading of peritoneal macrophages was examined one day and 3 days after infection. The results in Table 1 showed that the numbers of peritoneal macrophages and spread cells were significantly higher in bestatintreated mice than in normal controls on day 1 . However, the difference between them was no more significant on day 3.

Development of DTH to LM in bestatintreated mice was studied. Mice were divided into two groups. Hundred $\mu \mathrm{g}$ of bestatin was given iv daily for 3 days. All mice were concurrently infected iv with $1 \times 10^{2} \mathrm{LM}$ as the immunizing dose an hour after the last injection of bestatin. FPT was carried out on day 5, 7 and 9 after infection. As shown in Table 2, the levels of DTH were higher in bestatin-treated mice than those in controls. The difference between both groups was statistically significant to $P<0.05$ on day 7.

The data mentioned above indicate that pretreatment with bestatin enhanced the resistance to LM infection. Such enhanced resistance was associated with increased rate of spreading of macrophages at an early time of infection and with increased level of DTH to LM at a later stage. In general, acquired immunity against LM arises concomitantly with DTH at later stages after the 5th day of infection. It depends on specifically committed T-lymphocytes which activate macrophages as effector cells against $\mathrm{LM}^{8,9)}$. Our results in Fig. 2 showed that the growth of LM in bestatin-treated mice was clearly inhibited at the early times of infection when the acquired immunity did not arise yet, indicating that bestatin caused strong activation of macrophages without immunological process. BRULEYRosset et al. using the in vitro cytostatic test described that macrophage activation was obtained after the administration of the high doses of bestatin in aged mice ${ }^{10)}$. Moreover our results showed that treatment with bestatin caused the rapid and increased development of DTH to LM. SAITo et al. found that bestatin stimulated the blastogenesis of guinea pig lymphocytes triggered with polyclonal mitogen such as phytohemagglutinin, concanavalin A, pokeweed mitogen and lipopolysaccharide ${ }^{11)}$. MÜLLER et al. described that bestatin increased the incorporation rate of $\left[{ }^{3} \mathrm{H}\right]$ thymidine into DNA only in $\mathrm{T}$ cells ${ }^{12}$. IsHIzUKA et al. reported that bestatin was mito- genic on spleen cells and caused the proliferation of $\mathrm{T}$ cells probably through the activation of macrophages ${ }^{13)}$. It, therefore, seems that bestatin activates primarily macrophages and T-lymphocytes which mediate the DTH and acquired immunity to LM.

\section{Acknowledgments}

We thank Dr. Kotaro Sugiyama, Professor emeritus of Kyushu University, Director of Kyushu Welfare Pension Hospital, for helpful discussion and advice.

\section{References}

1) Umezawa, H.; T. Aoyagi, H. Suda, M. HamaDA \& T. TAKeuchI: Bestatin, an inhibitor of aminopeptidase B, produced by Actinomycetes. J. Antibiotics 29: 97 99, 1976

2) Suda, H.; T. Takita, T. Aoyagi \& H. UmeZAWA: The structure of bestatin. J. Antibiotics 29: $100 \sim 101,1976$

3) Umezawa, H.; M. Ishizuka, T. Aoyagi \& T. TAKEUCHI: Enhancement of delayed type hypersensitivity by bestatin, an inhibitor of aminopeptidase $\mathrm{B}$ and leucine aminopeptidase. J. Antibiotics 29: 857 859, 1976

4) Aoyagi, T.; M. Ishizuka, T. Takeuchi \& H. UMEZAWA: Enzyme inhibitors in relation to cancer therapy. Jpn. J. Antibiotics 30 Suppl.: S121 S132, 1977

5) Ishizuka, M.; T. Masuda, N. Kanbayashi, S. Fukasawa, T. Takeuchi, T. Aoyagi \& $\mathrm{H}$. UMEZAWA: Effect of bestatin on mouse immune system and experimental murine tumors. J. Antibiotics 33: 642 652, 1980

6) Youdim, S.; O. Stutman \& R. A. Good: Studies of delayed hypersensitivity of L. monocytogenes in mice. Nature of cells involved in passive transfers. Cell. Immunol. 6: 98 109, 1973

7) Ishibashi, T.; Y. Kitahara, A. Kajiki, Y. HaraDA, M. TAKAMOTO \& T. IsHibashI: Altered resistance to Listeria monocytogenes in diabetic mice. Jpn. J. Exp. Med. 51: $251 \sim 259,1981$

8) Mackaness, G. B.: The influence of immunologically committed lymphoid cells on macrophage activity in vivo. J. Exp. Med. 129: 973 992, 1969

9) North, R. J.: Importance of thymus-derived lymphocytes in cell-mediated immunity to infection. Cell. Immunol. 7: 166 176, 1973

10) Bruley-Rosset, M.; I. Florentin, N. Kiger, J. Schulz \& G. MAthÉ: Restoration of impaired immune functions of aged animals by chronic 
bestatin treatment. Immunology 38: $75 \sim 83$, 1979

11) Saito, M.; K. TAkegoshi, T. Aoyagi, H. UmeZAWA \& Y. NAGAI: Stimulatory effect of bestatin, a new specific inhibitor of aminopeptidases, on the blastogenesis of guinea pig lymphocytes. Cell. Immunol. 40: 247 262, 1978

12) Müller, W. E. G.; R. K. Zahn, J. Arendes,
N. Munsch \& H. Umezawa: Activation of DNA metabolism in T-cells by bestatin. Biochem. Pharmacol. 28: $3131 \sim 3137,1979$

13) Ishizuka, M.; H. Sato, Y. Sugiyama, T. Takeuchi \& H. Umezawa: Mitogenic effect of bestatin on lymphocytes. J. Antibiotics 33: $653 \sim 662,1980$ 